\title{
SISTEM PRESENSI MENGGUNAKAN NFC SMARTPHONE ANDROID DAN RASPBERRY PI (STUDI KASUS POLITEKNIK NEGERI MALANG)
}

\author{
Luqman Affandi ${ }^{1}$, Ekojono ${ }^{2}$, Ahmad Rizaldi ${ }^{3}$, \\ 1,2,3 Jurusan Teknologi Informasi, Politeknik Negeri Malang \\ ${ }^{1}$ laffandi@yahoo.com,2 ekojono2@polinema.ac.id, ${ }^{3}$ ahmadrizaldi1000@gmail.com
}

\begin{abstract}
Abstrak
Presensi adalah kegiatan pengambilan data untuk mencatat jumlah kehadiran. Ada beberapa metode pengambilan presensi yang sering digunakan, yaitu memanggil nama satu persatu dan memberikan kertas untuk ditanda-tangani satu persatu. Hal tersebut merupakan cara konvensional yang masih diterapkan di Politeknik Negeri Malang (Polinema). Pengambilan data kehadiran secara konvensional kurang efisien dan memiliki beberapa masalah diantaranya membutuhkan waktu yang lama dalam memanggil mahasiswa satu persatu, membutuhkan biaya untuk mencetak kertas dan kertas presensi sering kali terlambat dicetak dan didistribusikan. Berdasarkan permasalahan tersebut, muncul ide untuk memanfaatkan NFC pada smartphone Android untuk melakukan proses presensi pada setiap mahasiswa. Sistem menggunakan Representational State Transfer (REST) untuk komunikasi data. Sistem presensi Jurusan Teknologi Informasi (JTI) Polinema dengan cara konvensional membutuhkan waktu 1 jam. Dengan memanfaatkan teknologi ini, sistem presensi hanya membutuhkan waktu selama 5 menit. Berdasarkan pengujian alat pembaca NFC jarak optimal pembacaan tag adalah $<4 \mathrm{~cm}$ untuk smartphone dan $<3 \mathrm{~cm}$ untuk sticker NFC dan waktu rata-rata response sampai data terkirim ke database server adalah $0.47541 \mathrm{~s}$ untuk NFC smartphone dan 0.19975s untuk sticker NFC.
\end{abstract}

Kata kunci : Presensi, Near Field Communication (NFC), Representational State Transfer (REST)

\section{Pendahuluan}

Dewasa ini, ketergantungan manusia terhadap teknologi semakin berkembang pesat. Dengan adanya teknologi dapat memudahkan manusia dalam menjalankan aktivitasnya sehari-hari dengan mudah dan cepat. Contohnya bidang akademik sudah merasakan manfaatnya seperti SIAKAD, E-Learning dan lain sebagainya. Apalagi kegiatan akademik ditingkat perguruan tinggi yang sudah tidak dapat dilepaskan lagi dari kemajuan teknologi.

Salah satu pemanfaatan teknologi dibidang akademik adalah sistem presensi. Presensi adalah kegiatan pengambilan data untuk mencatat jumlah kehadiran. Presensi digunakan untuk mencatat kehadiran dari mahasiswa. Ada beberapa metode pengambilan presensi yang sering digunakan, yaitu memanggil nama satu persatu dan memberikan kertas untuk ditanda-tangani satu persatu. Hal tersebut merupakan cara konvensional yang masih diterapkan di Politeknik Negeri Malang. Pengambilan data kehadiran secara konvensional kurang efisien dan memiliki beberapa masalah diantaranya membutuhkan waktu yang lama dalam memanggil mahasiswa satu persatu, membutuhkan biaya untuk mencetak kertas dan sering terlambatnya kertas presensi. Selain itu, terdapat kemungkinan terjadi kesalahan dan lama dalam proses rekapnya yang disebabkan human error. Selain human error, kertas presensi yang dibagikan rawan hilang sehingga dosen akan sulit untuk melacak kehadiran dari mahasiswa keseluruhan.

Salah satu teknologi yang dapat digunakan adalah Near Field Communication (NFC). NFC dapat digunakan untuk saling bertukar data antara satu perangkat dengan perangkat lainnya dengan jarak 10 $\mathrm{cm}$. NFC merupakan gabungan anatara smartcard dan smartcard reader yang ditanam di dalam satu perangkat, umumnya perangkat yang digunakan adalah perangkat mobile seperti smartphone. Salah satu perangkat yang banyak menggunakan teknologi NFC adalah smartphone Android. Dalam proses presensi, smartphone akan mengirimkan nomor IMEI (International Mobile Equipment identity) sebagai nomor unik dengan menggunakan teknologi NFC. Nomor IMEI adalah suatu nomor unik yang dimiliki oleh setiap perangkat mobile yang dapat dijadikan sebagai identitas mahasiswa dalam melakukan proses presensi.

Berdasarkan permasalahan tersebut, muncul ide untuk memanfaatkan NFC pada smartphone android untuk melakukan proses presensi pada setiap mahasiswa. Sistem menggunakan Representational State Transfer (REST) untuk komunikasi data. Dengan memanfaatkan teknologi ini, diharapkan dapat menutupi kelemahan yang ada pada sistem presensi saat ini. 


\section{Landasan Teori}

\subsection{Presensi}

Presensi adalah sebuah kegiatan pengambilan data guna mengetahui jumlah kehadiran pada suatu acara. Setiap kegiatan yang membutuhkan informasi mengenai peserta tentu akan melakukan presensi. Hal ini juga terjadi pada proses belajar. Kegunaan absensi ini terjadi pada pihak pelajar dan pihak pengada proses belajar mengajar. Salah satu kegunaan absensi ini kepada pihak pelajar antara lain adalah dalam perhitungan kemungkinan pelajar untuk mengikuti ujian dan salah satu kegunaan informasi absensi ini kepada pihak pengada kegiatan belajar mengajar antara lain untuk melakukan evaluasi kepada kepuasaan pelajar terhadap suatu mata pelajaran dan pembuatan tolak ukur ke depan guna pemberian ilmu yang lebih baik[1].

\subsection{Near Field Communication (NFC)}

Near Field Communication (NFC) merupakan teknologi komunikasi baru dengan menggunakan induksi magnet berbasis teknologi Radio Frequency Identification (RFID). NFC mulai dikembangkan pada tahun 2002 oleh NXP dan Sony. Mereka berhasil membangun Forum NFC pertama bersama dengan Nokia. Sejak saat itu Forum NFC memiliki lebih dari 150 anggota dan peneliti yang terlibat dari beberapa perusahaan dan organisasi. Pada forum ini juga NFC dipromosikan dan secara resmi mengeluarkan sertifikasi untuk perangkat-perangkat yang mengadopsi teknologi NFC. NFC bisa juga disebut sebagai generasi kedua dari teknologi RFID [1].

NFC beroperasi pada frekuensi $13,56 \mathrm{MHz}$ dengan kecepatan transmisi pengiriman mencapai 424 $\mathrm{kbit} / \mathrm{s}$. Jarak transmisi NFC sekitar 4-10 cm. Perbedaan antara NFC dan teknologi komunikasi contactless lainnya yaitu perangkat NFC dapat bersifat aktif - aktif (peer to peer) dan aktif - pasif. Oleh karena itu NFC selalu melibatkan inisiator (reader) dan target. Inisiator aktif menghasilkan medan RF (Radio Frequency) yang dapat memberikan kekuatan ke target yang pasif (tidak memiliki sumber daya). Hal ini memungkinkan target NFC untuk memiliki bentuk yang sangat sederhana seperti stiker, gantungan kunci, atau kartu yang tidak memerlukan energi khusus.

\subsection{Android}

Android merupakan sistem operasi berbasis Linux dan menyediakan platform terbuka bagi para pengembang untuk menciptakan aplikasi mereka. Pada awalnya, Google Inc. membeli Android Inc., yang membuat software untuk ponsel. Kemudian, untuk mengembangkan Android, dibentuklah Open Handset Alliance, yang terdiri dari 34 perusahaan hardware, software, dan telekomunikasi, termasuk Google Inc.,
HTC, Intel, Motorola, Qualcomm, T-Mobile, dan Nvidia[4].

Arsitektur Android terdiri dari Applications, Application Framework, Libraries, Android Runtime dan Kernel Linux dapat dilihat pada Gambar 1.

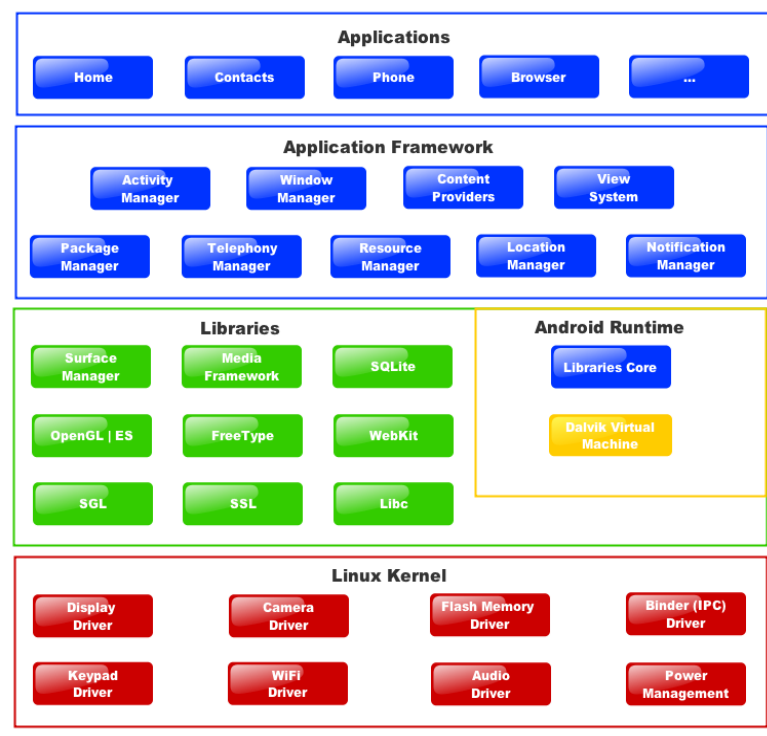

Gambar 1. Arsitektur Android

\subsection{Raspberry $\mathbf{P i}$}

Raspberry Pi adalah sebuah SBC (Single-Board Computer) seukuran kartu kredit. Raspberry pi telah dilengkapi dengan semua fungsi layaknya sebuah komputer lengkap, menggunakan SOC (System-on-aChip) ARM yang dikemas dan diintegrasikan di atas PCB (papan sirkuit). Raspberry Pi ini mampu bekerja layaknya komputer pada umumnya dengan kemampuan untuk menjalankan sistem operasi Linux dan aplikasinya seperti LibreOffice, multimedia (audio dan video), peramban web, ataupun programming[5].

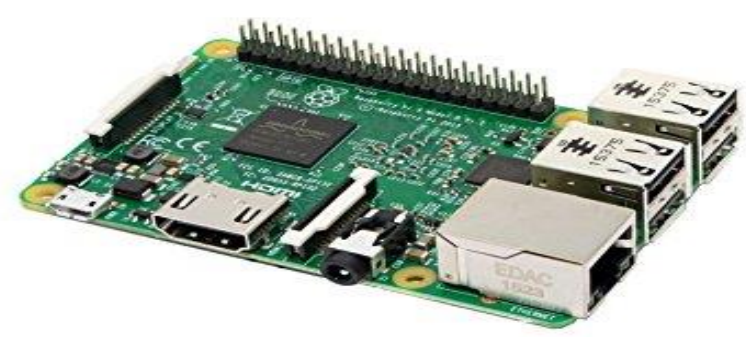

Gambar 2. Raspberry Pi

\subsection{Representational State Transfer (REST)}

Representational State Transfer (REST) merupakan suatu arsitektur metode komunikasi yang sering diterapkan dalam pengembangan layanan berbasis web. Penggunaan REST dapat membantu dalam melakukan pengiriman data yang diterima dari Raspberry Pi agar bisa disampaikan ke server yang nantinya melakukan kontrol terhadap data [4]. 


\subsection{International Mobile Station Equipment Identity (IMEI)}

IMEI sendiri merupakan singkatan dari International Mobile Equipment Identity. Melalui singkatan tersebut, dapat diketahui bahwa IMEI merupakan sebuah kode nomor yang dapat menunjukkan pembuat dan model dari ponsel tersebut. Secara sederhana, IMEI ini serupa dengan NIK pada Kartu Tanda Penduduk (KTP). Bagi operator seluler, kode nomor yang terdiri dari 15 hingga 16 digit ini juga memiliki fungsi untuk mendeteksi perangkat yang terdaftar dalam jaringan mereka.

\section{Analisis Dan Perancangan}

\subsection{Arsitektur Sistem}

Arsitektur sistem yang dirancang dapat dilihat pada

Gambar 3

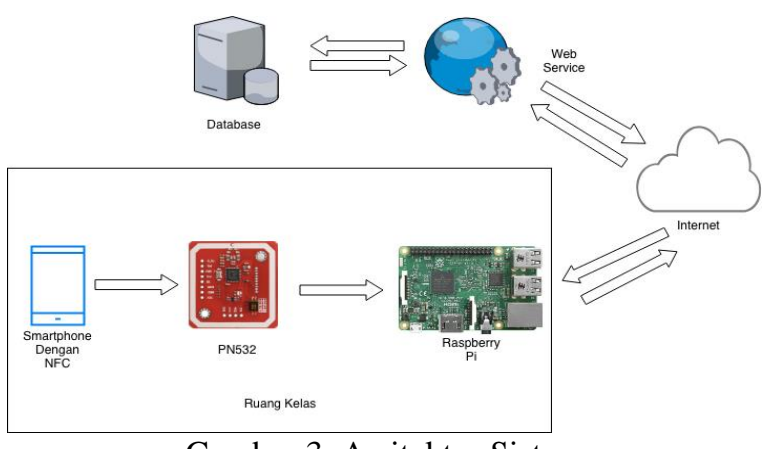

Gambar 3. Arsitektur Sistem

Pada gambar 3 Proses presensi dilakukan dengan menggunakan teknologi NFC, dalam sistem ini setiap mahasiswa memiliki NFC untuk discan pada NFC Reader. Kemudian NFC reader akan mengirimkan hasil ID dari pembacaan NFC dan kemudian akan dikirim ke raspberry pi. Kemudian ID akan dirkirim ke server untuk mengecek data yang ada diserver.

\subsection{Use Case Diagram}

Penjelasan dari Use Case Diagram dari sistem yang dibangun dapat dilihat pada gambar 3,4,5.

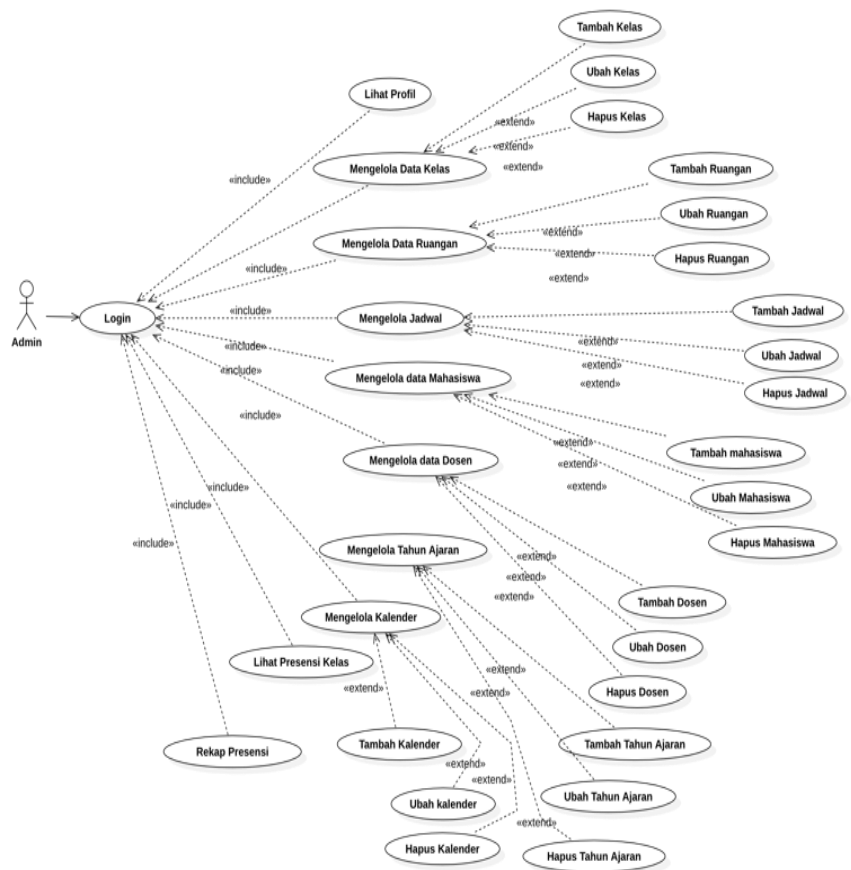

Gambar 4. Usecase Admin

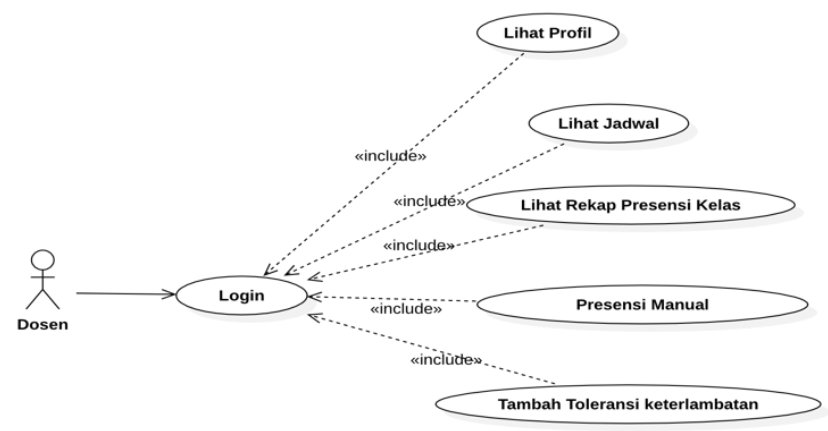

Gambar 5. Usecase Dosen

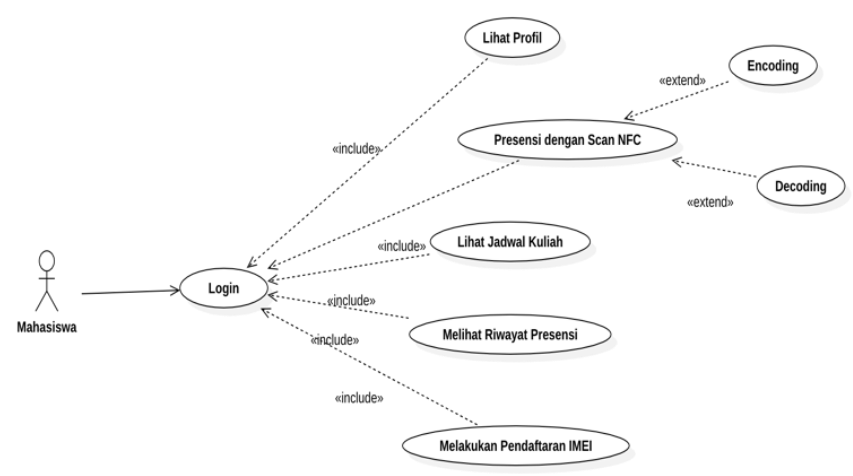

Gambar 6. Usecase Mahasiswa 


\subsection{Activity Diagram}

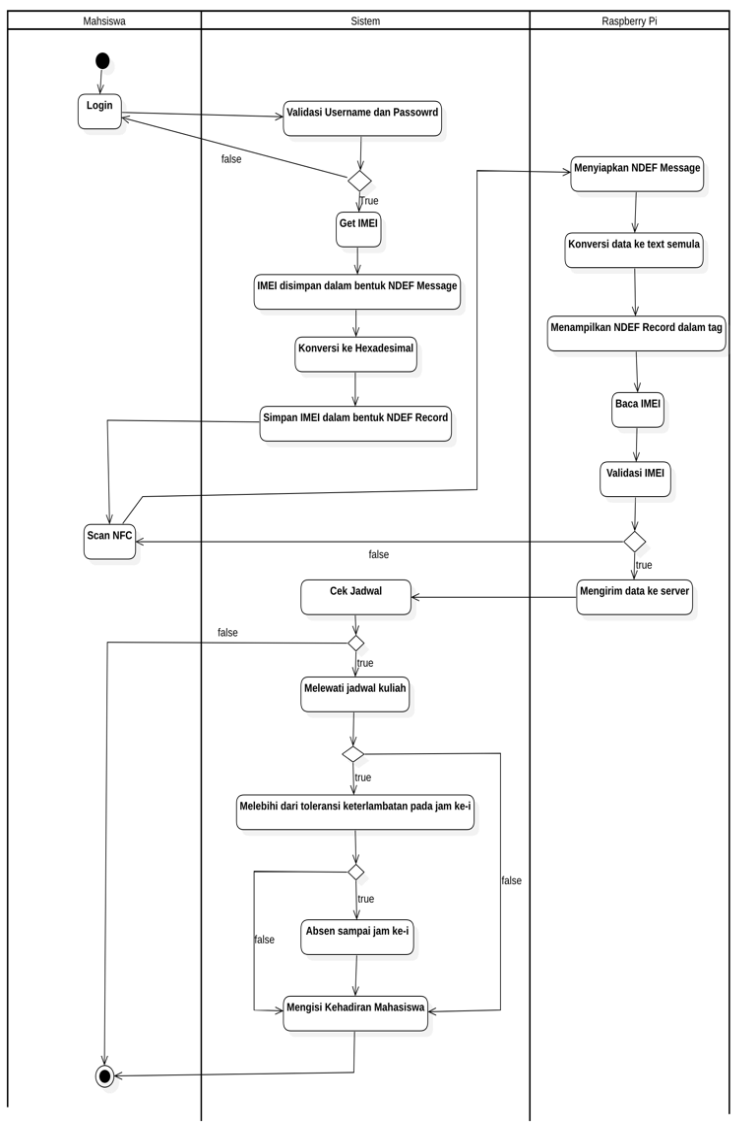

Gambar 7. Proses Presensi

Pada gambar 7 merupakan activity diagram untuk proses presensi. Proses tersebut dimulai dari login ke aplikasi, setelah berhasil login sistem akan melakukan encoding IMEI dari smartphone, kemudian mahasiswa memilih menu untuk melakukan scan NFC dan menempelkan smartphone ke NFC reader. Selanjutnya reader akan membaca NDEF message dan kemudian dilakukan proses decoding untuk mendapatkan NDEF record (IMEI). Selanjutnya setelah berhasil melakukan decoding IMEI akan divalidasi apakah data sudah terdaftar atau belum. Jika terdaftar maka akan dilakukan pengecekan jadwal mata kuliah. Setelah itu dilakukan pengecekan apakah melebihi dari jam kuliah. Jika iya maka akan dilakukan pencatatan alpha sebanyak pada jam kuliah ke-i. jika tidak maka sistem akan mengisi kehadiran mahasiswa.

\section{Implementasi dan pengujian}

Penelitian ini menghasilkan dua aplikasi yaitu aplikasi web dan mobile. Pada plikasi web diimplementasikan pada computer sedangkan aplikasi mobile diimplementasikan pada Android platform. Aplikasi web ditujukan kepada admin untuk mengelola data-data yang ada sedangkan aplikasi mobile ditujukan kepada mahasiswa dan dosen.

\subsection{Aplikasi Web}

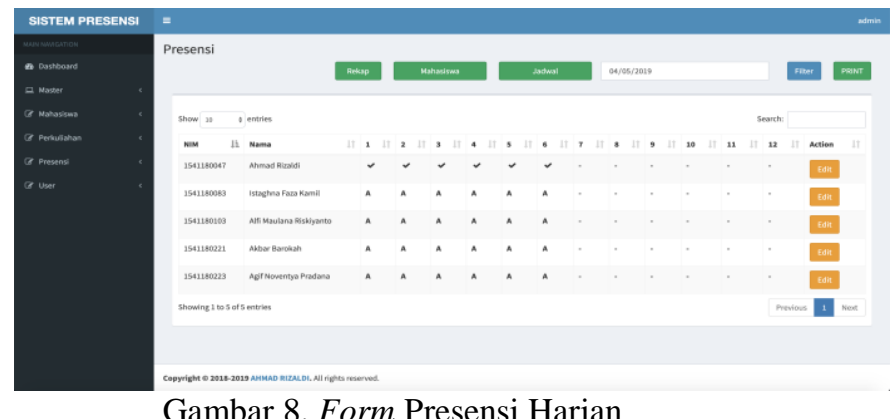

Gambar 8. Form Presensi Harian

Gambar 8 merupakan tampilan laporan presensi pada aplikasi web dengan pengguna admin. Pada tampilan ini, data akan difilter sebelumnya berdasarkan tahun ajara, dan kelas. Admin juga dapat memfilter presensi dengan mengganti tanggal.

\subsection{Aplikasi Android}

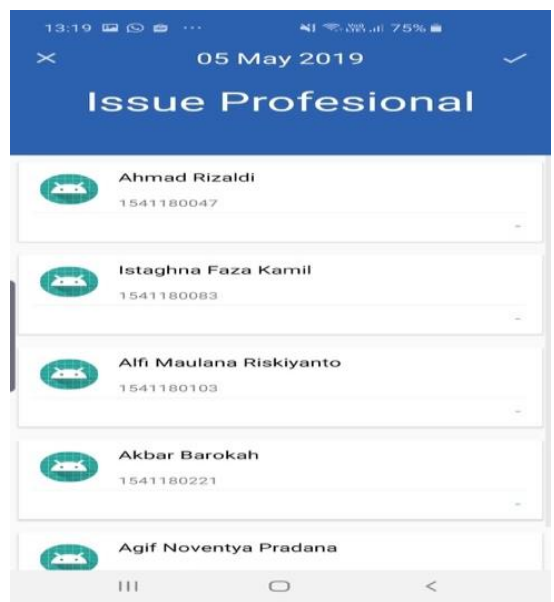

Gambar 9. Tampilan Presensi

Pada gambar 9 adalah tampilan presensi mahasiswa. Presensi akan secara otomatis berubah jika mahasiswa telah berhasil melakukan presensi.

\subsection{Hasil Pengujian}

Pengujian yang akan dilakukan dibagi menjadi beberapa tahapan sebagai berikut:

1. Pengujian modul reader untuk mengetahui konfigurasi yang sesuai guna optimalisasi pada proses pembacaan NFC. Pengujian tersebut meliputi :

a. Pengujian jarak yang dibutuhkan sensor PN532 untuk membaca tag

b. Pengujian waktu reader berdasarkan jarak

c. Pengujian jumlah pembacaan tag pada sensor PN532

d. Pengujian pengiriman IMEI untuk proses presensi ke web service

2. Pengujian fungsional sistem yang telah dirancang. a. Pengujian jarak yang dibutuhkan 
Tabel 1. Pengujian Jarak yang Dibutuhkan

\begin{tabular}{|l|l|l|l|l|l|l|l|l|}
\hline Jarak & T1 & T2 & T3 & T4 & T5 & T6 & T7 & T8 \\
\hline $\mathbf{5} \mathbf{~ c m ~}$ & X & X & X & X & X & X & X & X \\
\hline $\begin{array}{l}\mathbf{4 . 5} \\
\mathbf{c m}\end{array}$ & X & X & X & X & X & X & X & X \\
\hline $\mathbf{4} \mathbf{c m}$ & $\checkmark$ & $\checkmark$ & X & X & $\checkmark$ & $\checkmark$ & X & X \\
\hline $\begin{array}{l}\mathbf{3 . 5} \\
\mathbf{c m}\end{array}$ & $\checkmark$ & $\checkmark$ & $\checkmark$ & $\checkmark$ & $\checkmark$ & $\checkmark$ & $\checkmark$ & $\checkmark$ \\
\hline $\mathbf{3 ~ c m}$ & $\checkmark$ & $\checkmark$ & $\checkmark$ & $\checkmark$ & $\checkmark$ & $\checkmark$ & $\checkmark$ & $\checkmark$ \\
\hline $\begin{array}{l}\mathbf{2 . 5} \\
\mathbf{c m}\end{array}$ & $\checkmark$ & $\checkmark$ & $\checkmark$ & $\checkmark$ & $\checkmark$ & $\checkmark$ & $\checkmark$ & $\checkmark$ \\
\hline $\mathbf{2} \mathbf{c m}$ & $\checkmark$ & $\checkmark$ & $\checkmark$ & $\checkmark$ & $\checkmark$ & $\checkmark$ & $\checkmark$ & $\checkmark$ \\
\hline
\end{tabular}

Berdasarkan tabel 1 diatas, dapat disimpulkan bahwa jarak sensor PN532 yang optimal dapat membaca tag adalah $<4 \mathrm{~cm}$.

b. Pengujian waktu reader berdasarkan jarak

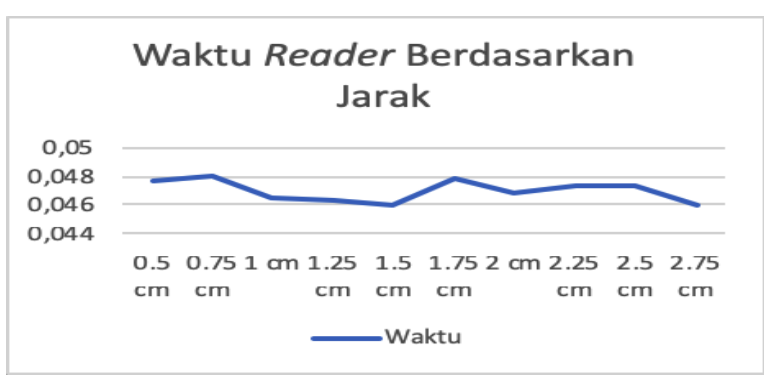

Gambar 10. Grafik waktu reader

Dari grafik pada gambar 10 dapat diambil kesimpulan bahwa jauh/dekatnya jarak tapping tidak berpengaruh terhadap waktu pembacaan. Untuk pengujian ini, didapatkan waktu rata-rata yaitu sebesar 0.04698s.

c. Pengujian waktu response sampai data tersimpan ke database

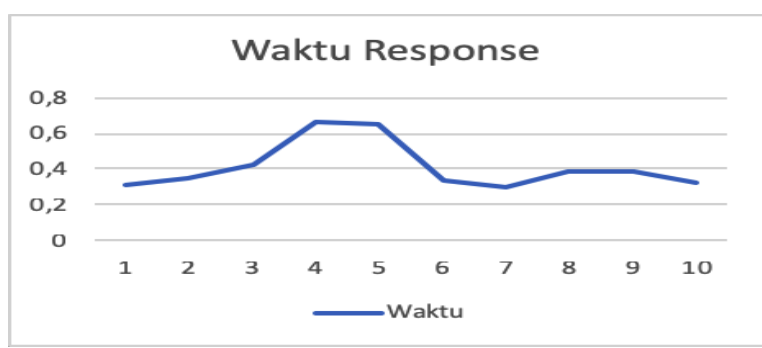

Gambar 11. Grafik waktu response

Dari grafik pada gambar 11 dapat diambil kesimpulan bahwa waktu response dipengaruhi oleh koneksi ke web server. Untuk pengujian ini, didapatkan waktu rata-rata yaitu sebesar 0.41431s.

d. Pengujian pembacaan NFC

Tabel 2. Tabel Pengujian Pembacaan NFC

\begin{tabular}{|l|l|}
\hline Percobaan Ke & Status \\
\hline 1 & Sukses \\
\hline 2 & Gagal \\
\hline 3 & Sukses \\
\hline 4 & Sukses \\
\hline 5 & Sukses \\
\hline 6 & Sukses \\
\hline 7 & Sukses \\
\hline 8 & Sukses \\
\hline 9 & Sukses \\
\hline 10 & Sukses \\
\hline
\end{tabular}

Berdasarkan tabel 2 dapat dilihat bawha dari 10 kali percobaan, 9 diantaranya berhasil dibaca oleh sensor, dan 1 percobaan. gagal saat dibaca pada sensor. Jadi persentase keberhasilan dalam pembacaan tag adalah sebesar $90 \%$.

e. Uji Coba Fungsional

Tabel 3. Hasil Pengujian Aplikasi

\begin{tabular}{|c|c|c|c|c|}
\hline Case & Input & $\begin{array}{l}\text { Valid- } \\
\text { asi }\end{array}$ & $\begin{array}{c}\text { Hasil } \\
\text { Ujii }\end{array}$ & Status \\
\hline \multirow[t]{2}{*}{ Login } & $\begin{array}{l}\text { Userna } \\
\text { me dan } \\
\text { passwo } \\
\text { rd }\end{array}$ & $\begin{array}{l}\text { Userna } \\
\text { me dan } \\
\text { passwo } \\
\text { rd } \\
\text { valid }\end{array}$ & $\begin{array}{l}\text { Login } \\
\text { Berhas } \\
\text { il }\end{array}$ & Diterima \\
\hline & & $\begin{array}{l}\text { Userna } \\
\text { me dan } \\
\text { passwo } \\
\text { rd } \\
\text { invalid }\end{array}$ & $\begin{array}{l}\text { Login } \\
\text { Gagal }\end{array}$ & \multirow[t]{2}{*}{ Diterima } \\
\hline Login & $\begin{array}{l}\text { Userna } \\
\text { me dan } \\
\text { passwo } \\
\text { rd }\end{array}$ & $\begin{array}{l}\text { Userna } \\
\text { me dan } \\
\text { passwo } \\
\text { rd } \\
\text { valid }\end{array}$ & $\begin{array}{l}\text { Login } \\
\text { Berhas } \\
\text { il }\end{array}$ & \\
\hline $\begin{array}{l}\text { Lihat } \\
\text { Kelas }\end{array}$ & & & $\begin{array}{l}\text { Data } \\
\text { Kelas } \\
\text { Ditam } \\
\text { pilkan }\end{array}$ & Diterima \\
\hline \multirow[t]{2}{*}{$\begin{array}{l}\text { Tamb } \\
\text { ah } \\
\text { Kelas }\end{array}$} & $\begin{array}{l}\text { Nama } \\
\text { kelas }\end{array}$ & $\begin{array}{l}\text { Data } \\
\text { Valid }\end{array}$ & $\begin{array}{l}\text { Data } \\
\text { berhasi } \\
1 \\
\text { disimp } \\
\text { an }\end{array}$ & \multirow[t]{2}{*}{ Diterima } \\
\hline & & $\begin{array}{l}\text { Data } \\
\text { Invalid }\end{array}$ & $\begin{array}{l}\text { Data } \\
\text { tidak } \\
\text { berhasi } \\
1 \\
\text { disimp } \\
\text { an }\end{array}$ & \\
\hline $\begin{array}{l}\text { Edit } \\
\text { Kelas }\end{array}$ & $\begin{array}{l}\text { Nama } \\
\text { Kelas }\end{array}$ & $\begin{array}{l}\text { Data } \\
\text { Valid }\end{array}$ & $\begin{array}{l}\text { Data } \\
\text { berhasi } \\
1 \\
\text { disimp } \\
\text { an }\end{array}$ & Diterima \\
\hline
\end{tabular}




\begin{tabular}{|c|c|c|c|c|}
\hline Case & Input & $\begin{array}{c}\text { Valid- } \\
\text { asi }\end{array}$ & $\begin{array}{c}\text { Hasil } \\
\text { Uji }\end{array}$ & Status \\
\hline & & $\begin{array}{l}\text { Data } \\
\text { Invalid }\end{array}$ & $\begin{array}{l}\text { Data } \\
\text { tidak } \\
\text { berhasi } \\
1 \\
\text { disimp } \\
\text { an }\end{array}$ & \\
\hline \multirow[t]{2}{*}{$\begin{array}{l}\text { Delet } \\
e \\
\text { Kelas }\end{array}$} & \multirow[t]{2}{*}{$\begin{array}{l}\text { Tombo } \\
1 \text { delete } \\
\text { ditekan }\end{array}$} & $\begin{array}{l}\text { Tombo } \\
1 \quad o k \\
\text { ditekan }\end{array}$ & $\begin{array}{l}\text { Data } \\
\text { kelas } \\
\text { dihapu } \\
\text { s }\end{array}$ & \multirow[t]{2}{*}{ Diterima } \\
\hline & & $\begin{array}{l}\text { Tombo } \\
1 \\
\text { cancel } \\
\text { ditekan }\end{array}$ & $\begin{array}{l}\text { Data } \\
\text { kelas } \\
\text { tidak } \\
\text { dihapu } \\
\mathrm{s}\end{array}$ & \\
\hline $\begin{array}{l}\text { Lihat } \\
\text { Maha } \\
\text { siswa }\end{array}$ & & & $\begin{array}{l}\text { Data } \\
\text { Mahasi } \\
\text { swa } \\
\text { Ditam } \\
\text { pilkan }\end{array}$ & Diterima \\
\hline \multirow[t]{2}{*}{$\begin{array}{l}\text { Tamb } \\
\text { ah } \\
\text { Maha } \\
\text { siwa }\end{array}$} & $\begin{array}{l}\text { Nim, } \\
\text { nama }\end{array}$ & $\begin{array}{l}\text { Data } \\
\text { valid }\end{array}$ & $\begin{array}{l}\text { Data } \\
\text { berhasi } \\
1 \\
\text { disimp } \\
\text { an }\end{array}$ & \multirow[t]{2}{*}{ Diterima } \\
\hline & & $\begin{array}{l}\text { Data } \\
\text { invalid }\end{array}$ & $\begin{array}{l}\text { Data } \\
\text { tidak } \\
\text { berhasi } \\
1 \\
\text { disimp } \\
\text { an }\end{array}$ & \\
\hline \multirow[t]{2}{*}{$\begin{array}{l}\text { Edit } \\
\text { Maha } \\
\text { siswa }\end{array}$} & $\begin{array}{l}\text { Nim, } \\
\text { nama }\end{array}$ & $\begin{array}{l}\text { Data } \\
\text { valid }\end{array}$ & $\begin{array}{l}\text { Data } \\
\text { berhasi } \\
1 \\
\text { disimp } \\
\text { an }\end{array}$ & \multirow[t]{2}{*}{ Diterima } \\
\hline & & $\begin{array}{l}\text { Data } \\
\text { invalid }\end{array}$ & $\begin{array}{l}\text { Data } \\
\text { tidak } \\
\text { berhasi } \\
1 \\
\text { disimp } \\
\text { an }\end{array}$ & \\
\hline \multirow[t]{2}{*}{$\begin{array}{l}\text { Delet } \\
e \\
\text { maha } \\
\text { siswa }\end{array}$} & $\begin{array}{l}\text { Tombo } \\
1 \text { delete } \\
\text { ditekan }\end{array}$ & $\begin{array}{l}\text { Tombo } \\
1 \quad o k \\
\text { ditekan }\end{array}$ & $\begin{array}{l}\text { Data } \\
\text { mahasi } \\
\text { swa } \\
\text { dihapu } \\
\text { s }\end{array}$ & \multirow[t]{2}{*}{ Diterima } \\
\hline & & $\begin{array}{l}\text { Tombo } \\
1 \\
\text { cancel } \\
\text { ditekan }\end{array}$ & $\begin{array}{l}\text { Data } \\
\text { mahasi } \\
\text { swa } \\
\text { tidak } \\
\text { dihapu } \\
\text { s }\end{array}$ & \\
\hline $\begin{array}{l}\text { Lihat } \\
\text { dosen }\end{array}$ & & & $\begin{array}{l}\text { Data } \\
\text { dosen } \\
\text { ditamp } \\
\text { ilkan }\end{array}$ & \\
\hline
\end{tabular}

\begin{tabular}{|c|c|c|c|c|}
\hline Case & Input & $\begin{array}{c}\text { Valid- } \\
\text { asi }\end{array}$ & $\begin{array}{c}\text { Hasil } \\
\text { Uji }\end{array}$ & Status \\
\hline \multirow[t]{2}{*}{$\begin{array}{l}\text { Tamb } \\
\text { ah } \\
\text { dosen }\end{array}$} & \multirow[t]{2}{*}{$\begin{array}{l}\text { Nip, } \\
\text { nama }\end{array}$} & $\begin{array}{l}\text { Data } \\
\text { valid }\end{array}$ & $\begin{array}{l}\text { Data } \\
\text { berhasi } \\
1 \\
\text { disimp } \\
\text { an }\end{array}$ & \multirow[t]{2}{*}{ Diterima } \\
\hline & & $\begin{array}{l}\text { Data } \\
\text { invalid }\end{array}$ & $\begin{array}{l}\text { Data } \\
\text { tidak } \\
\text { berhasi } \\
1 \\
\text { disimp } \\
\text { an }\end{array}$ & \\
\hline \multirow[t]{2}{*}{$\begin{array}{l}\text { Edit } \\
\text { dosen }\end{array}$} & \multirow[t]{2}{*}{$\begin{array}{l}\text { Nip, } \\
\text { nama }\end{array}$} & $\begin{array}{l}\text { Data } \\
\text { valid }\end{array}$ & $\begin{array}{l}\text { Data } \\
\text { berhasi } \\
1 \\
\text { disimp } \\
\text { an }\end{array}$ & \multirow[t]{2}{*}{ Diterima } \\
\hline & & $\begin{array}{l}\text { Data } \\
\text { invalid }\end{array}$ & $\begin{array}{l}\text { Data } \\
\text { tidak } \\
\text { berhasi } \\
1 \\
\text { disimp } \\
\text { an }\end{array}$ & \\
\hline \multirow[t]{2}{*}{$\begin{array}{l}\text { Delet } \\
e \\
\text { Dose } \\
\mathrm{n}\end{array}$} & \multirow[t]{2}{*}{$\begin{array}{l}\text { Tombo } \\
1 \text { delete } \\
\text { ditekan }\end{array}$} & $\begin{array}{l}\text { Tombo } \\
1 \quad o k \\
\text { ditekan }\end{array}$ & $\begin{array}{l}\text { Data } \\
\text { dosen } \\
\text { dihapu } \\
\mathrm{s}\end{array}$ & \multirow[t]{2}{*}{ Diterima } \\
\hline & & $\begin{array}{l}\text { Tombo } \\
1 \\
\text { cancel } \\
\text { ditekan }\end{array}$ & $\begin{array}{l}\text { Data } \\
\text { dosen } \\
\text { tidak } \\
\text { dihapu } \\
\mathrm{s}\end{array}$ & \\
\hline $\begin{array}{l}\text { Lihat } \\
\text { Mata } \\
\text { Kulia } \\
\text { h }\end{array}$ & & & $\begin{array}{l}\text { Data } \\
\text { mata } \\
\text { kuliah } \\
\text { ditamp } \\
\text { ilkan }\end{array}$ & Berhasil \\
\hline \multirow[t]{2}{*}{$\begin{array}{l}\text { Tamb } \\
\text { ah } \\
\text { mata } \\
\text { kulia } \\
\text { h }\end{array}$} & \multirow{2}{*}{$\begin{array}{l}\text { Kode } \\
\text { mata } \\
\text { kuliah, } \\
\text { nama } \\
\text { mata } \\
\text { kuliah, } \\
\text { semest } \\
\text { er }\end{array}$} & $\begin{array}{l}\text { Data } \\
\text { valid }\end{array}$ & $\begin{array}{l}\text { Data } \\
\text { berhasi } \\
1 \\
\text { disimp } \\
\text { an }\end{array}$ & \multirow[t]{2}{*}{ Diterima } \\
\hline & & $\begin{array}{l}\text { Data } \\
\text { invalid }\end{array}$ & $\begin{array}{l}\text { Data } \\
\text { tidak } \\
\text { berhasi } \\
1 \\
\text { disimp } \\
\text { an }\end{array}$ & \\
\hline \multirow[t]{2}{*}{$\begin{array}{l}\text { Edit } \\
\text { mata } \\
\text { kulia } \\
\mathrm{h}\end{array}$} & \multirow{2}{*}{$\begin{array}{l}\text { Kode } \\
\text { mata } \\
\text { kuliah, } \\
\text { nama } \\
\text { mata } \\
\text { kuliah, } \\
\text { semest } \\
\text { er }\end{array}$} & $\begin{array}{l}\text { Data } \\
\text { valid }\end{array}$ & $\begin{array}{l}\text { Data } \\
\text { berhasi } \\
1 \\
\text { disimp } \\
\text { an }\end{array}$ & \multirow[t]{2}{*}{ Diterima } \\
\hline & & $\begin{array}{l}\text { Data } \\
\text { invalid }\end{array}$ & $\begin{array}{l}\text { Data } \\
\text { tidak } \\
\text { berhasi } \\
1 \\
\text { disimp } \\
\text { an } \\
\end{array}$ & \\
\hline
\end{tabular}


Berdasarkan pengujian yang dilakukan pada aplikasi web dapat dilihat status pengujian dari setiap fungsi valid, maka disimpulkan bahwa aplikasi ini berjalan dengan baik dan sesuai yang diharapkan.

\section{Kesimpulan dan saran}

\subsection{Kesimpulan}

Berdasarkan penelitian yang telah dilakukan mengenai "Sistem Presensi Menggunakan NFC Smartphone Android Dan Raspberry Pi (Studi Kasus Politeknik Negeri Malang)" maka diambil kesimpulan bahwa:

1. Penelitian ini telah berhasil membuat sistem yang digunakan untuk melakukan proses presensi dengan memanfaatkan teknologi NFC. Sistem ini berfungsi dengan baik sesuai dengan pengujuan yang dilakukan

2. Jarak optimal sensor PN532 dapat membaca tag NFC adalah dengan jarak $3 \mathrm{~cm}$.

3. Waktu response rata-rata pada saat mahasiswa scan sampai tersimpan kedalam database adalah 0.41431 s.

Sistem berjalan sesuai apa yang diharapkan, sistem dapat berjalan secara otomatis mencatat presensi mahasiswa secara detail. Dengan adanya sistem ini diharapkan dapat mengatasi masalah pencatatan kehadiran secara konvensional.

\subsection{Saran}

Sistem presensi dengan teknologi ini bisa dikembangkan untuk device lain seperti IOS.

\section{Daftar Pustaka:}

[1] Pallavi M V and S B Mallikarjuna, "Android Application for Mobile Attendance Using NFC", 2017.

[2] Rian Ariansyah P and, Eko Budi Setiawan, "PEMANFAATAN NEAR FIELD COMMUNICATION (NFC) SEBAGAI MEDIA PEMBAYARAN DI PESONA NIRWANA WATERPARK,", Vol. 5, No. 1,2016.

[3] NOFITA RISMAWATI, "SISTEM ABSENSI DOSEN MENGGUNAKAN NEAR FIELD COMMUNICATION

(NFC) TECHNOLOGY",2016.

[4] Mychael Maoeretz Enge, "T Pengembangan Sistem Presensi Pegawai Berbasis Android Menggunakan Teknologi Near Field Communication" belum dipublikasikan.

[5] Fajril Akbar, Meza Silvana \& Surya Afnarius, "Implementasi Near Field Communication (NFC) dan Kartu RFID sebagai Perangkat Mobile Presensi Mahasiswa”,2015.

[6] Farzana Akte, Amatul Bushra Akhi, Nusrat Jahan Farin, Md. Mohsin Khondoker, Md. Golam
Saklayen, "IoTSAMS: A Novel Framework for Internet of Things (IoT) Based Smart Attendance Management System",2018.

[7] Mahesh Sutar, Mahesh Patil, Sachin Waghmare, "IoTSAMS: A Novel Framework for Internet of Things (IoT) Based Smart Attendance Management System", 2016. 
Volume 6, Edisi 3, Mei 2020

$82 \mid \mathrm{H}$ a 1 a $\mathrm{m}$ a $\mathrm{n}$ 